Egyptian Journal of Aquatic Biology \& Fisheries

Zoology Department, Faculty of Science,

Ain Shams University, Cairo, Egypt.

ISSN $1110-6131$

Vol. 25(5): 627 - 643 (2021)

www.ejabf.journals.ekb.eg

\title{
Utilization of Taro Leaves in Diet of the Nile Tilapia Oreochromis nloticus
}

\author{
Raky F. Attalla ${ }^{1 *}$; Sabry S. El-Serafy ${ }^{2}$; Susan H. Fadda ${ }^{1}$; \\ Nassr-Allah H. Abdel-Hameid ${ }^{2}$
}

1- Fish nutrition, National institute of oceanography and fisheries.

2- Fish biology, Faculty of science, Benha University.

*corresponding author: rakyniof@yahoo.com

ARTICLE INFO

\section{Article History:}

Received: Oct. 24, 2021

Accepted: Oct. 28, 2021

Online: Nov. 11, 2021

Keywords:

Nile tilapia,

Colocasia esculenta,

Growth performance,

Feed utilization,

Liver metabolites.

\section{INTRODUCTION}

Eighty-four days feeding trial was conducted to address the growth performance, feeding efficacy rate, body indices, and biochemical parameters of the mono-sex Nile tilapia, when fed different substitution levels of soy and maize with dried taro (Colocasia esculenta) leaves, compared to a control diet. This trial was followed by a 14-days fish digestibility experiment. All treatments were duplicated by using two equal cement basins with 5 equal parts containing 100 fish per each with a recorded initial weight $(23.39 \pm 0.43 \mathrm{~g})$. All growth responses were significantly affected, whether in the four examined fish groups or the control group $(\mathrm{P}<0.05)$. Compared to the control, the lowest muscle lipid and the highest muscle protein contents were recorded in fish fed diet 3, (20 $\%$ boiled soybean $+40 \%$ yellow corn). A significant improvement was detected in the plasma total protein and the immunoglobulin $(p<0.05)$ of the tilapia fed the four examined diets when compared to the control. Similarly, the highest protein digestibility was recorded for the 4 aforementioned fish groups ( $\mathrm{p}<0.05)$. Meanwhile, an insignificant survival rate was observed for both groups; the treated and the control. Furthermore, the liver index and liver composition were significantly affected with regard to the tested fish groups when compared to the control. Results indicated that soy and corn substituted with taro leaves, which contain the important amino and fatty acids required for fish, can significantly promote growth and may provide the market with a low cost-effective and eco-friendly fish diet as well.

Aquaculture is a considerable growing industry which enriches the world witha white protein source. Different trials have been organized to enhance feed efficiency and growth performance of the tilapia species.

Fishmeal is considered the most palatable animal protein source in aquatic feeds because of its balanced amino acid profile, high digestibility, in addition to its efficacy as a source of essential n-3 polyenoic fatty acids (Hardy \& Tacon, 2002). However, despite their lower percentage of plant protein, deficiency in amino acids and the antinutritional agents, plant protein feedstuffs have been used to replace fishmeal. Moreover, compared 
to fish meal, plant protein is more constantly available in lower costs, but its bad effect on the palatability and digestibility has been recognized (Hardy, 2010). A deficiency in certain essential amino acids is one of the major issues associated with plant protein sources, when added to other ingredients (Ogunji et al., 2008). Better trials are recommended to examine the efficiency of partially or totally substituting fishmeal, soybean or any other expensive sources with less expensive and easily available plant protein sources. This step would reduce the high dependence on the afore- mentioned protein sources used for fish feed and simultaneously help increasing the nutritional feed quality.

Several studies were performed to evaluate the use of different plants as additives or replacements for fishmeal, soybean, and corn meal in aqua feeds (Toan \& Preston, 2010; Chhay et al., 2010; Castillo \& Gatlin, 2015; Raky et al., 2021a, b, c).The nutritional values of some tubers and roots are not equivalent to the real values of their potential ability to supply people with specific nutrition; for instance, the low carbohydrate ingredients written on some items (Carpenter et al., 2001). Among the root crops, taro is one which contains a great amount (87\%) of carbohydrates, fibre, and minerals in developing countries in Asia and Western Africa. Taro (Colocasia esculenta), a member of the Araceae family, is an ancient crop grown all over the humid tropics and is known for its edible corms and leaves, as well as its traditional ceremonial uses (Wang, 1983). Though the taro corm lacks protein, fat, and most vitamins, itcontains a significant amount of dietary fibre and minerals (Behera et al., 2009).

Taro corm is served as boiled, but people are not aware of the importance of its leaves. The taro leaf is cooked and eaten as a vegetable in Asia and often in tropical Africa (Akwee, 2015). The nutritional values are the main concern when a crop is being considered as a food source,thus informations on the nutritional contents of the root crops like taro are highly required (Hang \& Preston, 2009).

Taro leaves contain more values of beta-carotene $(135 \mu \mathrm{g})$, folic acid (3.28 $\mathrm{mg})$ and iron (1.35 mg) (Oueme \& Winston, 1999). The protein content in taro leaves is high (21 $\% \mathrm{DM})$ and rich with most of the limited amino acids compared to other tropical root crops, cereals and legumes (Ajijola et al., 2003). Taro leaves powder (Colocasia esculenta) is a significant protein supplement which can replace fish meal and soy meal due to its high protein digestibility and biological value (Chhay et al., 2010).

It is very important to supply reared fish with the required amounts of essential amino acids (EAAs) for their high positive effectson the muscle deposition of the cultured fish and the feed cost (Small \& Soares, 1999). Thus, formulating effective diets with suitable cost that would meet EAAs requirement can be a target (Kaushik \& Seiliez, 2010). In this context, to meet those requirements, the use of high quality proteins associated with low price has been concerned (El-Sayed, 2006; Webster \& Chhorn, 2006).

Compared to the corn, the amino acid and fatty acids composition of taro leaf were higher. Meanwhile, taro leaf has been considered as a good source of essential amino acid and fatty acid (Temesgen et al., 2017) and also, there is high ambivalence between the lysine, tryptophan, and methionine requirements for the tilapia. Mmanda et al. (2020) 
reported that several local feed ingredients have the potential to supply the EAA required for proper fish growth and health.

In addition, El-Tawil $\boldsymbol{e t}$ al. (2020) assessed that, growth performance parameters of the Nile tilapia, Oreocromis niloticus, improved $(\mathrm{p}<0.05)$ with the increasing the percentage used of taro leaves in case of substituting taro leaves meal for soybean meal in fish diets. The previous authors added that the values of feed efficiency measurements were increased significantly in fish; the highest values were recorded with fish fed up to $20 \%$ taro leaves. Results cleared that fish proximate analysis affected $(p<0.05)$. Moreover, the supplementation of taro leaves in the fish diet reduced the cost of one $\mathrm{kg}$ diet compared the control.

\section{Principal objective}

Substitute expensive diet ingredients by unconventional plant materials, which are uneaten by people, are good trials to reduce cost of production and increase supply of protein and carbohydrate in fish diet.

The study aimed to investigate the effect of partial replacement of the two ingredients (soy and corn) by dried taro leaves in diets for the mono sex Nile tilapia.

\section{Specific objectives}

1- To investigate nutrient (\% DM basis), amino acid, and fatty acid of taro leaf meal.

2- To investigate dry matter intake, protein intake, digestibility, protein efficiency, mean weight gain, and feed conversion efficiency of fish fed diets containing different substitution levels.

3- To determine the nutrient composition, biochemical properties, and fish health indicators after use of taro leaf meal.

\section{MATERIALS AND METHODS}

\section{Taro leaves powder preparation}

Fresh taro leaves (Colocasia esculenta L.) were obtained from local market, washed and air dried. The dried samples were powdered into particle size of $1.6 \mathrm{~mm}$ and packaged in polythene bags to formulate the diets for various feed chemical analyses.

The nutritional composition of taro leaves and other main ingredients of fish ration are showed in Table (1).

\section{Experimental design and Preparation of diets}

Four diets containing different percentages of substitution of boiled soybean meal (BSM) and yellow corn (YC) with 30, 45, 60, and 75\% taro leaves meal (TM) were performed as follow: D1 (10\% BSM+20\% YC); D2 (15\% BSM +30\% YC); D3 ( $20 \%$ $\mathrm{BSM}+40 \% \mathrm{YC})$, and $\mathrm{D} 4(25 \% \mathrm{BSM}+50 \% \mathrm{YC})$.

Feed ingredients were formulated for test diets and chemically analyzed (Table $2 \& 3$ ).

Fish were acclimated under optimal conditions for a week before starting the trial. The mono-sex Nile tilapia, with mean initial body weight of $23.39 \pm 0.43 \mathrm{~g}$, were fed twice a day at 10 am and $3 \mathrm{pm}$ for 84 days. Fish weight was calculated biweekly in order to adjust feeding rate $(3 \%)$. The water was changed twice a week. 
Table 1. Main ingredient composition (\%)

\begin{tabular}{|l|c|c|c|c|}
\hline Chemical composition & Fish meal & Taro leaves & Yellow corn & Soybean meal \\
\hline Crude Protein (CP) & 59.02 & 26.2 & 7.5 & 41.44 \\
\hline Ether extract (EE) & 8.91 & 5.9 & 3.5 & 0.5 \\
\hline Crude fiber (CF) & 0.96 & 18.5 & 8.8 & 7.0 \\
\hline Ash & 18.8 & 19.1 & 5.5 & 6.0 \\
\hline Nitrogen free extract (NFE) & 4.31 & 30.3 & 55.1 & 35.06 \\
\hline Dry matter (DM) & 92 & 18.3 & 86 & 92 \\
\hline Gross energy (GE)* & 18.5 & 17.14 & 16.0 & 17.4 \\
\hline
\end{tabular}

$* \mathrm{GE}=(\mathrm{CP} * 5.65+\mathrm{EE} * 9.65+\mathrm{CF} * 4.2+\mathrm{NFE} * 4.2) * 4.182 / 100$

Table 2. Experimental diet formulations

\begin{tabular}{|l|c|c|c|c|c|}
\hline & \multicolumn{5}{|c|}{ Examined diets } \\
\cline { 2 - 6 } & Control & D1 & D2 & D3 & D4 \\
\hline Fish meal & 15 & 15 & 15 & 15 & 15 \\
\hline Corn gluten meal & 5 & 5 & 5 & 5 & 5 \\
\hline Boiled soybean & 30 & 27.0 & 25.5 & 24.0 & 22.5 \\
\hline Yellow corn & 30 & 24.0 & 21.0 & 18.0 & 15.0 \\
\hline Taro leaves & 0 & 9.0 & 13.5 & 18.0 & 22.5 \\
\hline Wheat bran & 16.5 & 16.5 & 16.5 & 16.5 & 16.5 \\
\hline Sunflower oil & 2 & 2 & 2 & 2 & 2 \\
\hline Premix* & 1 & 1 & 1 & 1 & 1 \\
\hline Cr $_{2} \mathbf{O}_{3}$ & 0.5 & 0.5 & 0.5 & 0.5 & 0.5 \\
\hline
\end{tabular}

*One kg premix contained:

Vitamins: $48 \times 10^{5} \mathrm{I} . \mathrm{U}(\mathrm{A}), 6 \times 10^{2} \mathrm{mg}\left(\mathrm{B}_{6}\right), 20 \mathrm{mg}$ (biotin), $8 \times 10^{5} \mathrm{I} . \mathrm{U} .\left(\mathrm{D}_{3}\right), 144 \mathrm{mg}(\mathrm{E})$, $400 \mathrm{mg}\left(\mathrm{B}_{1}\right), 1600 \mathrm{mg}\left(\mathrm{B}_{2}\right), 4 \times 10^{3} \mathrm{mg}$ (pantothenic acid), $4 \mathrm{mg}\left(\mathrm{B}_{12}\right), 4 \times 10^{2} \mathrm{mg}$ (niacin), $2 \times 10^{5} \mathrm{mg}$ (choline chloride), and $400 \mathrm{mg}$ (folic acid).

Minerals: $12 \times 10^{3} \mathrm{mg}$ iron, $16 \times 10^{3} \mathrm{mg}$ manganese, $12 \times 10^{2} \mathrm{mg}$ copper, $120 \mathrm{mg}$ iodine, $80 \mathrm{mg}$ cobalt, $40 \mathrm{mg}$ selenium, and $16 \times 10^{3} \mathrm{mg}$ zinc.

Table 3. Nutritional composition of experimental diets

\begin{tabular}{|l|c|c|c|c|c|}
\hline \multirow{2}{*}{$\begin{array}{l}\text { Nutritional } \\
\text { parameter }\end{array}$} & \multicolumn{5}{|c|}{ Experimental diets } \\
\cline { 2 - 6 } DM & Control & D1 & D2 & D3 & D4 \\
\hline CP & 89.19 & 82.98 & 79.87 & 76.76 & 73.66 \\
\hline EE & 29.62 & 29.95 & 30.12 & 30.28 & 30.45 \\
\hline CF & 5.30 & 5.60 & 5.76 & 5.91 & 6.06 \\
\hline Ash & 4.07 & 5.43 & 6.10 & 6.78 & 7.46 \\
\hline NFE & 6.13 & 7.45 & 8.11 & 8.77 & 9.43 \\
\hline GE & 42.80 & 40.14 & 38.82 & 37.49 & 36.16 \\
\hline
\end{tabular}




\section{Experimental fish measurements}

Fish were weighed biweekly to calculate mean weight gain (MWG), daily weight gain (DWG), and specific growth rate (SGR). In addition, feed intake (FI) and protein intake of feed were recorded to determine protein efficiency and feed conversion ratios (PER \& FCR) and protein productive value (PPV) according to Cho and Kaushik (1985) as the following:

MWG, $\mathrm{g} /$ fish $=$ [final body weight $(\mathrm{g})$ - initial body weight $(\mathrm{g})]$

DWG, g/fish /day = [BWG (g) / Experimental period (days) $]$

SGR, \%g/day $=[$ Ln final weight - Ln initial weight $] /$ Experimental period (day)*100

$\mathbf{F C R}=$ feed intake $(\mathrm{g}) /$ body weight gain $(\mathrm{g})$

PER = gain in weight $(\mathrm{g}) /$ protein intake in feed $(\mathrm{g})$

PPV, $\%=100$ [protein gain in fish $(\mathrm{g}) /$ protein intake in feed $(\mathrm{g})$ ]

Survival rate $\%=100$ [Initial number of fish stocked-Mortality] / Initial number of fish stocked.

Apparent protein digestibility (APD) was measured by using the method of Furukawa and Tasukahara (1966). The uneaten diet and faeces were collected by siphoning once daily in the last 15 days of the trial. Feed or faeces was carefully collected before first feeding. After about 30 min of feeding, uneaten feed was collected. Faeces were collected separately after 2 hours then filtered and dried at $60^{\circ} \mathrm{C}$ and stored to determine the chemical composition.

\section{Water quality parameters}

During the experimental period, water quality parameters (water temperature, dissolved oxygen and $\mathrm{pH}$ (measured daily); total ammonia, nitrite, and nitrate) were weekly measured. The unionized ammonia (UIA) was calculated according to the method of Zhang et al. (2018).

\section{Laboratory analysis}

\subsection{Chemical composition}

Samples of feed ingredients, fish diets and fish muscles were analyzed for crude protein (CP), ether extract (EE), crude fibre (CF) and ash using the AOAC (2012) reference methods.

\subsection{Biochemical analysis}

\subsubsection{Fatty and Amino acids composition}

Taro leaf was processed as a powder prior to the analysis. The leaf samples were tested for fatty acid and amino acid composition by using the method recommended by Li and Watkin (1998) that was applied for the determination of fatty acid and amino acids. This method was evaluated by Tidwell $\boldsymbol{e t}$ al. (1993).

\subsubsection{Liver analysis}

At the end of the trial, liver samples of 15 fish were taken randomly from each pond, then liver tissues were homogenized with $5 \mathrm{ml}$ distilled water to determine the 
following parameters; liver glycogen was determined ( $\mathrm{g} / 100 \mathrm{~g}$ fresh tissue) by the formula, using modified method of Handle (1965).

Glycogen $=($ Absorbance sample/Absorbance standard $) \mathrm{x}$ Conc. of standard $\mathrm{x}$ (V. of dil. factor/ Wt. of tissues).

The total liver lipid was extracted with a mixture of 2 chloroform:1 Methanol following the description in the study ofBligh and Dyre (1959), then $0.5 \mathrm{ml}$ sulphuric acid was added to the dried lipid extract by using the method of Zollner and Kirsch (1962).

Lipid = (Absorbance sample/Absorbance standard) $\mathrm{x}$ Conc. of standard $\mathrm{x}$ (V. of dil. factor/ Wt. of tissues).

Total liver protein was homogenated in trichloroacetic acid to $0.2 \mathrm{ml}$ of tissue, centrifuged $1008 \mathrm{xg}$, using the formula of Gornall et al. (1949) as follows:

Protein $=($ Absorbance sample/Absorbance standard $) \mathrm{x}$ Conc. of standard $\mathrm{x}(\mathrm{V}$. of dil. factor/ Wt. of tissues).

\section{Physiological parameters}

\subsection{Body indices}

Livers and guts of the experimental fish were taken at the end of the feeding trial and weighed to calculate liver and gut (HSI \&GSI respectively) as follows:

HSI $=($ liver weight $/$ fish total weight $) \times 100$;

GSI $=($ gut weight $/$ fish total weight $) \times 100$.

\subsection{Blood parameters}

At the end of the trial, blood samples were collected from the fish caudal veins. Blood was centrifuged at $1008 \mathrm{xg}$ for $15 \mathrm{~min}$. Samples were subjected to the determination of plasma protein (PTP) according to method of Armstrong and car (1964). The Immunoglobulin's (IgM and IgD) were measured by using the method of Feinstein et al. (1985).

\section{Data analysis}

The data were subjected to analysis of variance (ANOVA) using general linear models (GLM) procedure, and the software used was SPSS (Version 16.0) (SPSS, 1997). Duncan's multiple range tests (Duncan, 1955) were used to compare between means of the control and treated groups.

The model of analysis was as follows:

$\mathbf{Y}_{\mathrm{ij}}=\boldsymbol{\mu}+\mathbf{T}_{\mathbf{i}}+\mathbf{E}_{\mathrm{ij}}$

$\mu=$ the overall mean;

$\mathrm{T}_{\mathrm{i}}=$ the effect of treatment;

$E_{i j}=$ the random error. 


\section{RESULTS AND DISCUSSION}

\section{Water quality}

The mean values of water quality $( \pm \mathrm{SD})$ are recorded in Table (4). All water quality parameters are within the acceptable ranges for rearing the tilapia (Makori et al., 2017).

Table 4. Water physico-chemical parameters

\begin{tabular}{|l|c|}
\hline \multicolumn{1}{|c|}{ Water parameter } & Value \\
\hline Temperature $\mathrm{C}$ & $27.4 \pm 1.14$ \\
\hline Dissolved oxygen $(\mathrm{mg} / \mathrm{L})$ & $5.9-6.6 \pm 0.21$ \\
\hline pH & $7.3 \pm 0.15$ \\
\hline Total ammonia nitrogen $(\mathrm{mg} / \mathrm{L})$ & $0.023 \pm 0.00$ \\
\hline Nitrate $(\mathrm{mg} / \mathrm{L})$ & $0.72 \pm 0.03$ \\
\hline Nitrite $(\mathrm{mg} / \mathrm{L})$ & $0.022 \pm 0.010$ \\
\hline
\end{tabular}

\section{Biochemical investigation}

Analysis of essential amino acid and fatty acid composition of taro, soy and corn are important variables considered in the present study (Table 5\&6) and (Fig. 1).

The present results recorded that, taro leaves powder had a rich source of mainly essential amino and fatty acids which are highly important for fish health, especially the three amino acids (methionine, lysine, and tryptophan) and the unsaturated fatty acids, which compensate methionine deficiency in soy and corn (Raky, 2001; Temesgen et al., 2017; Lyu et al., 2019). Additionally, Jiang (1999) reported that taro leaves are rich in essential amino acids and its protein content is approximately $23 \%$. .

Table 5. Essential amino acids of taro leaves, soy and corn $(\mathrm{g} / 100 \mathrm{~g})$

\begin{tabular}{|l|c|c|c|}
\hline Essential amino acids \% & Taro leaves & Soybean & Yellow corn \\
\hline Histidine & 2.61 & 1.2 & 1.30 \\
\hline Threonine & 4.75 & 1.88 & 1.31 \\
\hline Valine & 6.02 & 1.12 & 1.51 \\
\hline Methionine & 2.34 & 0.65 & 1.93 \\
\hline Cysteine & 1.91 & 0.65 & 0.92 \\
\hline Phenylalanine & 6.02 & 2.64 & 2.44 \\
\hline Arginine & 1.66 & 3.21 & 2.53 \\
\hline Isoleucine & 4.85 & 2.41 & 2.27 \\
\hline Lysine & 5.94 & 3.11 & 1.27 \\
\hline Leucine & 8.95 & 3.57 & 3.82 \\
\hline Tryptophan & 3.25 & 1.01 & 0.84 \\
\hline
\end{tabular}




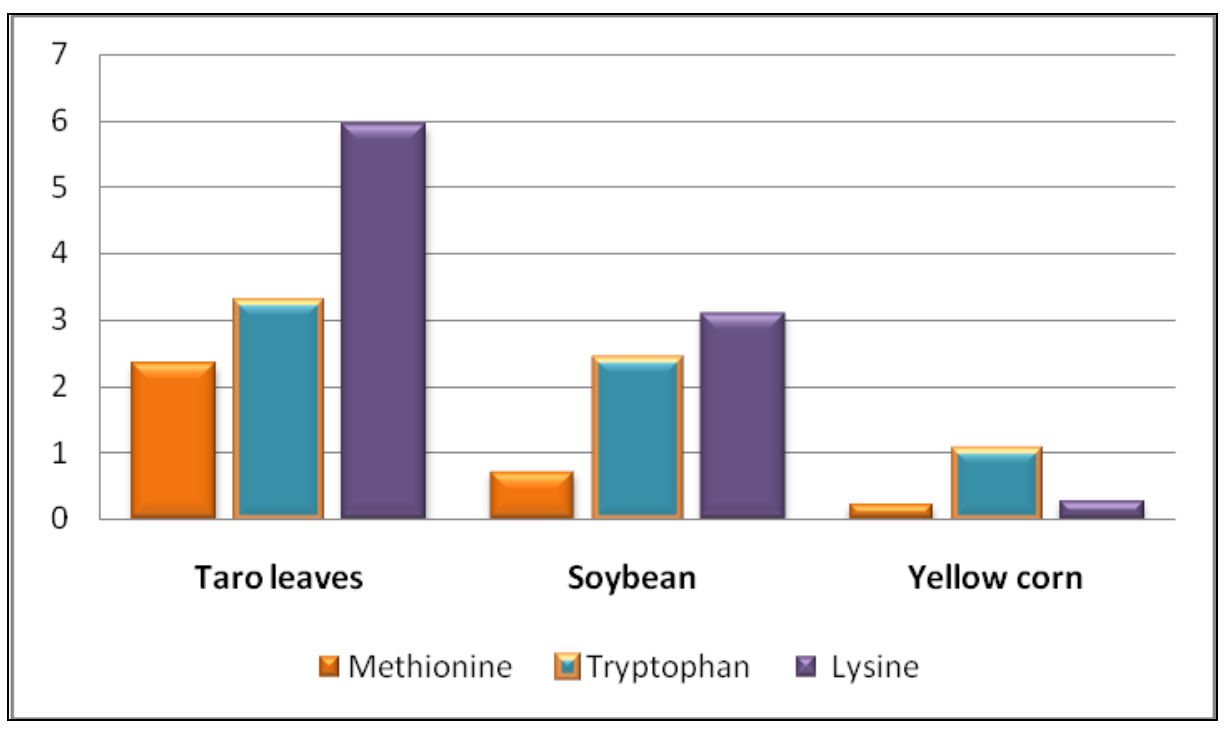

Fig. 1. Taro leaves rich in the EAA (\%) relative to soy and corn

The total unsaturated fatty acids $(314.91 \mathrm{~g} / 100 \mathrm{~g})$ were the dominant acids recorded in the present study. Similarly, Temesgen et al. (2018) stated that the high levels of unsaturated fatty acids in the taro are nutritionally rich $(322.98 \pm .55 \mathrm{~g} / 100 \mathrm{~g})$.

Table 6. Fatty acids (FA) composition of taro leaves (soy and corn) replacer

\begin{tabular}{|c|c|c|c|c|c|c|c|}
\hline \multicolumn{7}{|c|}{ Fatty acid ratios (g/ 100g) } \\
\hline \multicolumn{2}{|c|}{ Saturated FA } & \multicolumn{2}{c|}{ Mono unsaturated FA } & \multicolumn{2}{c|}{ Unsaturated FA } & \multicolumn{2}{c|}{ Poly-unsaturated FA } \\
\hline C14:0 & $2.50 \pm 0.11$ & $\mathrm{C} 14: 1$ & $0.32 \pm 0.03$ & $\mathrm{C} 18: 1(\mathrm{n}-9)$ & $223.61 \pm 2.1$ & $\mathrm{C} 18: 2(\mathrm{n}-6)$ & $54.01 \pm 1.00$ \\
\hline $\mathrm{C} 15: 0$ & $0.30 \pm 0.01$ & $\mathrm{C} 16: 1(\mathrm{n}-7)$ & $15.31 \pm 0.30$ & $\mathrm{C} 18: 2(\mathrm{n}-6)$ & $55.11 \pm 1.00$ & $\mathrm{C} 18: 3(\mathrm{n}-3)$ & $0.32 \pm 0.21$ \\
\hline C16:0 & $203.58 \pm 2.4$ & $\mathrm{C} 17: 1$ & $0.32 \pm 0.01$ & $\mathrm{C} 18: 3(\mathrm{n}-3)$ & $0.34 \pm 0.21$ & $\mathrm{C} 20: 1(\mathrm{n}-9)$ & $0.32 \pm 0.03$ \\
\hline $\mathrm{C} 17: 0$ & $0.32 \pm 0.01$ & $\mathrm{C} 18: 1(\mathrm{n}-9)$ & $220.61 \pm 2.1$ & $\mathrm{C} 20: 1(\mathrm{n}-9)$ & $0.34 \pm 0.03$ & $\mathrm{C} 20: 2(\mathrm{n}-6)$ & $0.32 \pm 0.01$ \\
\hline C18:0 & $100.81 \pm 1.1$ & $\mathrm{C} 20: 1(\mathrm{n}-9)$ & $0.32 \pm 0.03$ & $\mathrm{C} 20: 2(\mathrm{n}-6)$ & $0.34 \pm 0.01$ & $\mathrm{C} 20: 3(\mathrm{n}-6)$ & $0.31 \pm 0.04$ \\
\hline $\mathrm{C} 22: 0$ & $0.30 \pm 0.03$ & $\mathrm{C} 22: 1(\mathrm{n}-9)$ & $0.313 \pm 0.01$ & $\mathrm{C} 20: 3(\mathrm{n}-6)$ & $0.34 \pm 0.04$ & $\mathrm{C} 20: 4(\mathrm{n}-6)$ & $26.22 \pm 0.01$ \\
\hline $\mathrm{C} 24: 0$ & $0.32 \pm 0.02$ & $\mathrm{C} 24: 1(\mathrm{n}-9)$ & $0.313 \pm 0.02$ & $\mathrm{C} 20: 4(\mathrm{n}-6)$ & $27.32 \pm 0.01$ & $\mathrm{C} 20: 3(\mathrm{n}-3)$ & $0.31 \pm 0.03$ \\
\hline & & & & $\mathrm{C} 20: 3(\mathrm{n}-3)$ & $0.32 \pm 0.03$ & $\mathrm{C} 22: 1(\mathrm{n}-9)$ & $0.30 \pm 0.01$ \\
\hline & & & & $\mathrm{C} 22: 1(\mathrm{n}-9)$ & $0.313 \pm 0.01$ & $\mathrm{C} 22: 6(\mathrm{n}-3)$ & $5.80 \pm 0.02$ \\
\hline & & & & $\mathrm{C} 22: 6(\mathrm{n}-3)$ & $5.85 \pm 0.02$ & $\mathrm{C} 24: 1(\mathrm{n}-9)$ & $0.31 \pm 0.02$ \\
\hline & & & & $\mathrm{C} 24: 1(\mathrm{n}-9)$ & $0.33 \pm 0.02$ & & \\
\hline Total & $\mathbf{3 0 8 . 2 2}$ & & $\mathbf{2 3 7 . 5 1}$ & & $\mathbf{3 1 4 . 9 1}$ & & $\mathbf{8 8 . 0 3}$ \\
\hline
\end{tabular}

\section{Growth performance of Oreochromis niloticus}

The results of growth and feed utilization parameters as shown in Table (7) and Figs (2 - 5) improved principally for fish fed D3, (20\% soy $+40 \%$ corn) followed by fish fed D4, (25\% soy $+50 \%$ corn) which were replaced by taro leaves. These results may be due to the fact that taro leaf is rich with essential amino acid, unsaturated fatty acid, 
carbohydrates, and other nutritional components (Jiang, 1999; Oueme \& Winston, 1999; Ajijola et al., 2003; Chhay et al., 2010; Temesgen et al., 2018).

Table 7. Growth response parameters of fish fed examined diet

\begin{tabular}{|l|c|c|c|c|c|}
\hline \multirow{2}{*}{$\begin{array}{l}\text { Growth } \\
\text { parameter }\end{array}$} & Control & D1 & D2 & D3 & D4 \\
\cline { 2 - 6 } Initial weight $(\mathbf{g})$ & $23.18 \pm 0.45$ & $23.15 \pm 0.51$ & $23.33 \pm 0.43$ & $23.72 \pm 0.35$ & $23.55 \pm 0.32$ \\
\hline Final weight $(\mathbf{g})$ & $98.71^{\mathrm{d}} \pm 1.28$ & $99.38^{\mathrm{c}} \pm 1.14$ & $100.18^{\mathrm{bc}} \pm 1.22$ & $103.76^{\mathrm{a}} \pm 1.01$ & $101.20^{\mathrm{b}} \pm .92$ \\
\hline MWG (g) & $75.53^{\mathrm{d}} \pm 0.77$ & $76.23^{\mathrm{c}} \pm 0.82$ & $76.85^{\mathrm{c}} \pm 64$ & $80.04^{\mathrm{a}} \pm 0.70$ & $77.65^{\mathrm{b}} \pm 0.65$ \\
\hline DWG (g/day) & $0.90^{\mathrm{c}} \pm 0.02$ & $0.91^{\mathrm{b}} \pm 0.01$ & $0.91^{\mathrm{b}} \pm 0.01$ & $0.95^{\mathrm{a}} \pm 0.04$ & $0.92^{\mathrm{ab}} \pm 0.02$ \\
\hline SGR (\%) & $1.72^{\mathrm{c}} \pm 0.04$ & $1.73^{\mathrm{c}} \pm 0.02$ & $1.74^{\mathrm{b}} \pm 0.04$ & $1.76^{\mathrm{a}} \pm 0.05$ & $1.74^{\mathrm{b}} \pm 0.03$ \\
\hline FI (g) & $125.07^{\mathrm{d}} \pm 0.7$ & $125.65^{\mathrm{d}} \pm 0.8$ & $126.65^{\mathrm{c}} \pm 0.82$ & $130.54^{\mathrm{a}} \pm 1.62$ & $127.92^{\mathrm{b}} \pm 1.11$ \\
\hline SR\% & 97.00 & 98.00 & 97.00 & 98.00 & 100.00 \\
\hline
\end{tabular}

Values in the same row with different superscripts are significantly different $(\mathrm{P}<0.05)$

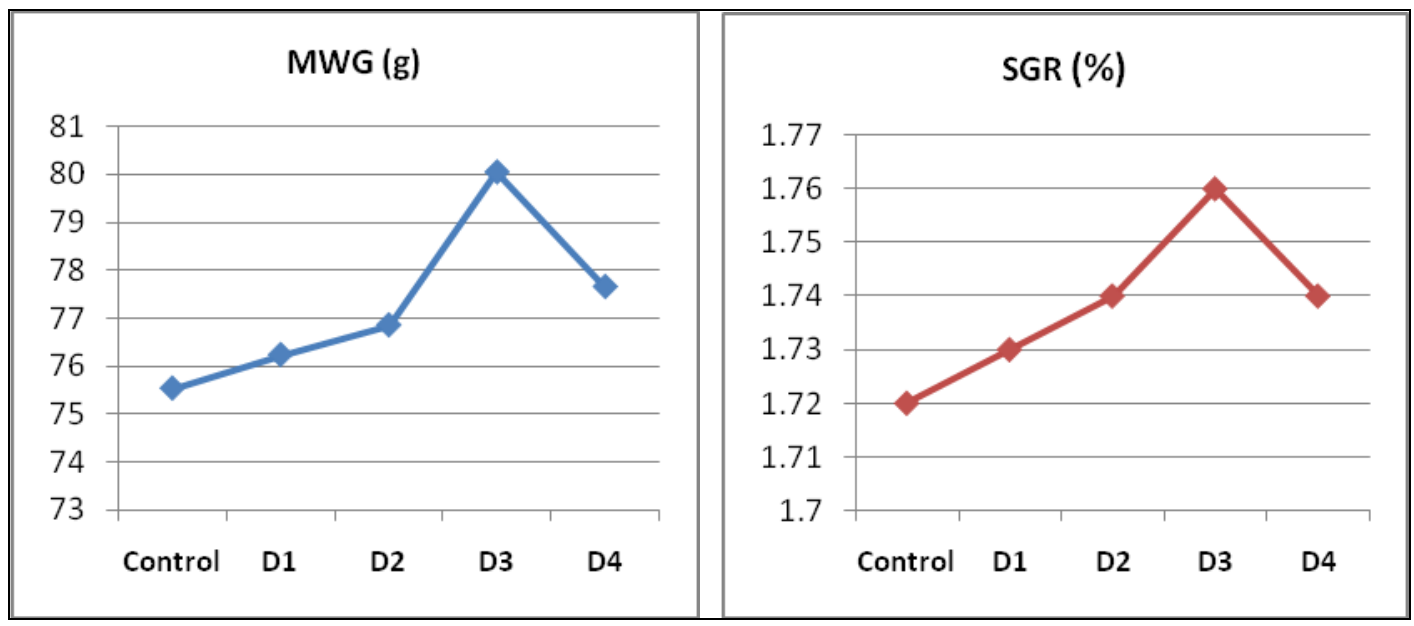

Fig. 2. Mean weight gain

Fig. 3. Specific growth rate

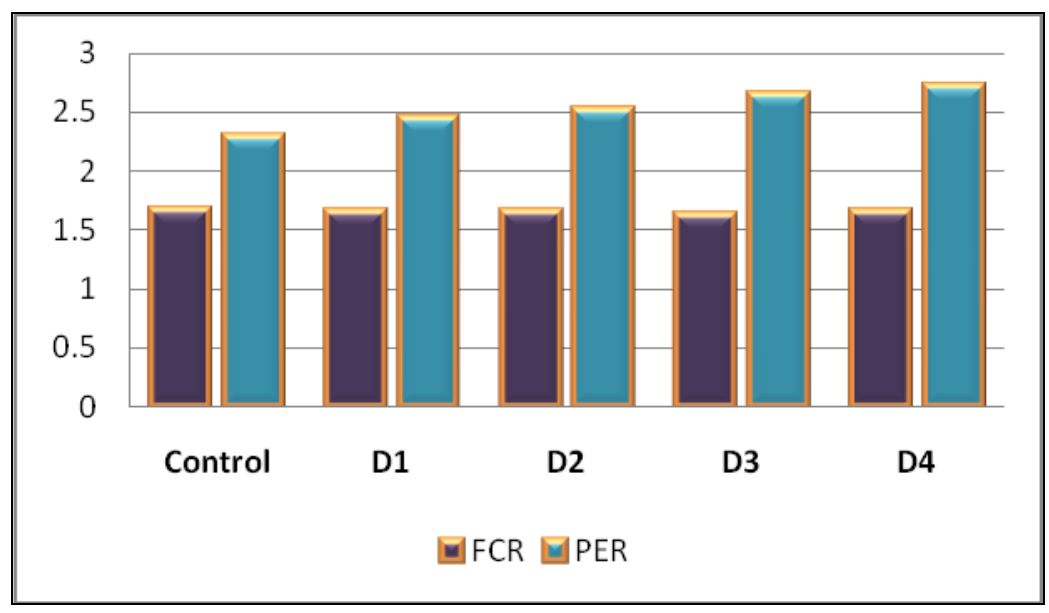

Fig. 4. Diet efficiency ratios 


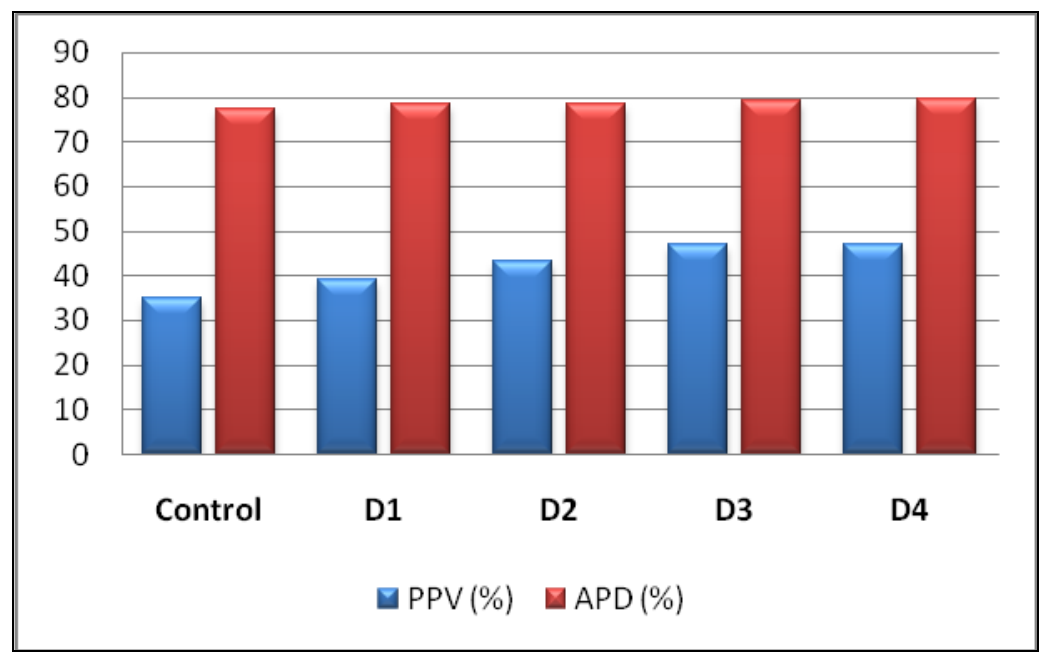

Fig. 5. Protein utilization

Moreover, El-Tawil et al. (2020) used taro leaves meal to substitute soybean meal in fish diets and deduced that the growth parameters of Oreochromis niloticus improved significantly with the increasing levels of taro leaves. They also found that feed efficiency measurements enhanced for the fish fed up to $20 \%$ taro leaves.

The present result agree with that of Mathia and Fotedar (2012) who used taro leaves as a complete replacement of shrimp meal protein in the tilapia diets and recorded an insignificant specific growth rate, survival rate, and apparent food conversion ratio. Wee and Wang (1987), Richter et al. (2003) and El-Saidy and Saad (2008) suggested that a complete replacement of plant protein may have some assorted effects on the growth performance. The replacement of soybean meal by taro leaves powder up to $25 \%$ may have an adverse effect on growth performance (El-Tawil et al., 2020).

Acceptable ranges of essential amino acid requirement for the tilapia diet were $1.43-1.62 \%$ for lysine, $0.17-0.6 \%$ for tryptophan, $0.53-1.13 \%$ for methionine, and $0.53-$ $2.1 \%$ for cysteine (El-Sayed, 2004). The current findings indicate that taro leaves have the potential to supply the EAA required for fish growth and health.

\section{Biological parameters}

Biological composition in the present study revealed that fish indices fluctuated insignificantly within the four test diets, while diet 3 (20\% soy $+40 \%$ corn) replaced by taro leaves gave the lowest indices compared to the control (Fig. 6 \&7). 


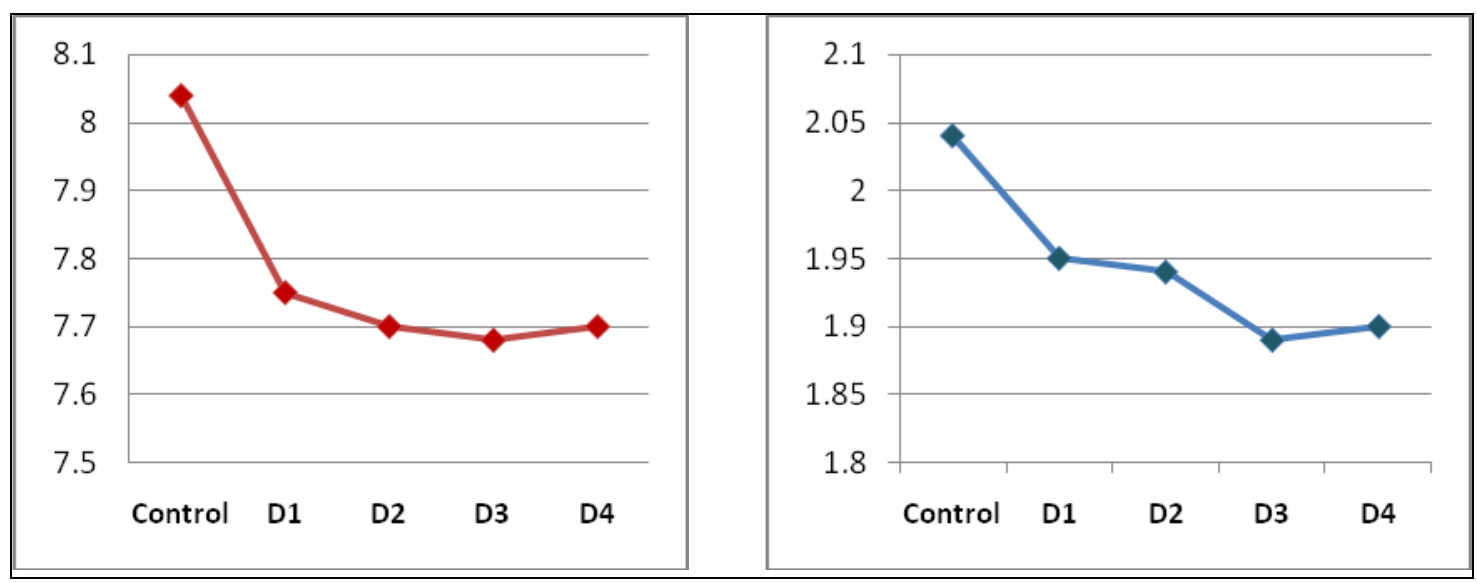

Fig. 6. Gastro-somatic index

Fig. 7. Hepato-somatic index

Robaina et al. (1995) reported that the deficiency of some important essential amino acids in soy and corn (e.g. methionine) may havealmost occurred, particularly in plant sources amino acids resulting in increasing liver weight. This may explain why hepato-somatic index were lower in fish fed the diets containing taro leaves.

\section{Muscle and liver composition of examined fish}

Present results in Table (8) show that, muscle protein content increased $(\mathrm{p}<0.05)$ with increasing the levels of taro leaf, while lipid content decreased, compared to the control.

The quality of feed protein highly effects on the protein composition of final products such as meat (Osek et al., 2011), also Melesse $\boldsymbol{e t}$ al. (2011) proved that the quality of protein and amino acid contents of feed enhanced muscle protein.

El-Tawil et al. (2020) recorded that fish protein content increased $(\mathrm{p}<0.05)$ with increasing taro levels accompanied with lipid decrease.

Table 8. Muscle composition of mono-sex tilapia at the end of the trials

\begin{tabular}{|l|c|c|c|c|c|}
\hline \multirow{2}{*}{$\begin{array}{l}\text { Chemical } \\
\text { composition }\end{array}$} & \multicolumn{5}{|c|}{ Experimental diets } \\
\cline { 2 - 6 } & Control & D1 & D2 & D3 & D4 \\
\hline DM & $24.25^{\mathrm{c}} \pm 0.91$ & $24.60^{\mathrm{c}} \pm 0.87$ & $25.70^{\mathrm{b}} \pm 0.92$ & $26.57^{\mathrm{a}} \pm 0.68$ & $26.38^{\mathrm{a}} \pm 0.74$ \\
\hline CP & $63.01^{\mathrm{c}} \pm 1.02$ & $65.17^{\mathrm{b}} \pm 0.96$ & $66.42^{\mathrm{ab}} \pm 0.58$ & $66.81^{\mathrm{a}} \pm 0.85$ & $65.95^{\mathrm{ab}} \pm 1.01$ \\
\hline EE & $19.73^{\mathrm{a}} \pm 0.52$ & $18.90^{\mathrm{b}} \pm 0.46$ & $18.70^{\mathrm{c}} \pm 0.67$ & $18.04^{\mathrm{d}} \pm 0.39$ & $19.01^{\mathrm{b}} \pm 0.40$ \\
\hline Ash & $13.05^{\mathrm{c}} \pm 0.27$ & $13.80^{\mathrm{b}} \pm 0.19$ & $13.90^{\mathrm{ab}} \pm 0.28$ & $14.09^{\mathrm{a}} \pm 0.31$ & $13.94^{\mathrm{ab}} \pm 0.12$ \\
\hline NFE & $4.21^{\mathrm{a}} \pm 0.02$ & $2.13^{\mathrm{b}} \pm 0.04$ & $0.98^{\mathrm{d}} \pm 0.01$ & $1.06^{\mathrm{c}} \pm 0.03$ & $1.10^{\mathrm{c}} \pm 0.01$ \\
\hline Moisture & $75.75^{\mathrm{a}} \pm 0.90$ & $75.40^{\mathrm{b}} \pm 0.80$ & $74.30^{\mathrm{c}} \pm 1.13$ & $73.43^{\mathrm{d}} \pm 0.75$ & $73.62^{\mathrm{d}} \pm 0.16$ \\
\hline
\end{tabular}


The results of liver metabolites shown in Table (9) and Fig. (8) reveal that, the fish fed test diets showed an increased trend for liver protein $(p<0.05)$ and glycogen $(p>0.05)$, while hepatic lipid exhibited an opposite trend $(\mathrm{p}<0.05)$.

Table 9. Liver metabolites g/100 tissue

\begin{tabular}{|l|l|l|l|l|l|}
\hline \multirow{2}{*}{ liver parameter } & \multicolumn{5}{|c|}{ Experimental diets } \\
\cline { 2 - 6 } & \multicolumn{1}{|c|}{ Control } & \multicolumn{1}{|c|}{ D1 } & D2 & D3 & D4 \\
\hline Hepatic protein & $22.79^{\mathrm{c}} \pm 1.00$ & $22.93^{\mathrm{c}} \pm 0.90$ & $23.92^{\mathrm{b}} \pm 1.00$ & $24.33^{\mathrm{a}} \pm 1.01$ & $23.95^{\mathrm{b}} \pm 0.95$ \\
\hline Hepatic lipids & $7.15^{\mathrm{a}} \pm 0.12$ & $7.04^{\mathrm{b}} \pm 0.15$ & $7.00^{\mathrm{ab}} \pm 0.13$ & $6.51^{\mathrm{d}} \pm 0.10$ & $6.72^{\mathrm{c}} \pm 0.05$ \\
\hline Hepatic glycogen & $4.23^{\mathrm{d}} \pm 0.09$ & $4.54^{\mathrm{b}} \pm 0.08$ & $4.67^{\mathrm{a}} \pm 0.08$ & $4.73^{\mathrm{a}} \pm 0.10$ & $4.45^{\mathrm{c}} \pm 0.09$ \\
\hline
\end{tabular}

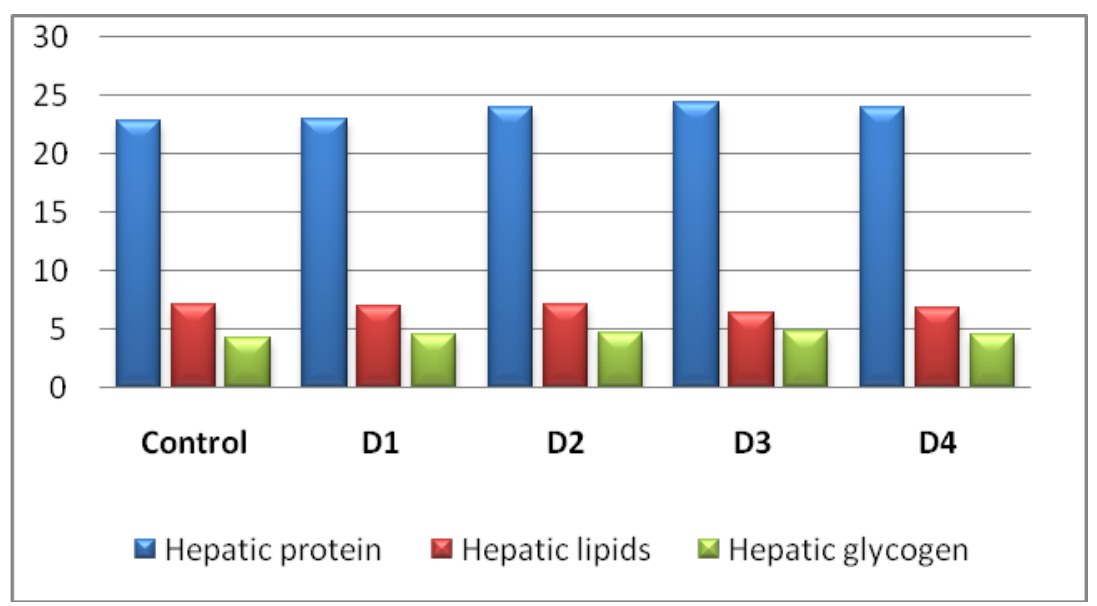

Fig 8. Liver metabolites (g/100g) tissue of mono-sex O. niloticus

\section{Haematological investigations}

The present study demonstrated that, when taro leaves wre evaluated as substitution of corn and soy, the plasma total protein (PTP), albumin, globulin (Table 10), and immunity indicator (IgM \& IgD) levels were significantly enhanced (Fig. $9 \& 10)$. Those results may be due to the bioactive compounds found in taro leaves (Pereira et al., 2018).

Plasma total protein is important to evaluate the nutritional state of the fish health condition (Olaniyi 2010, Pratriche et al., 2011). Extremely total protein and albumin have been reported to be directly responsive to protein intake and quality (Onifade $\boldsymbol{\&}$ Abu, 1998). 
Table 10. Biochemical blood analysis

\begin{tabular}{|l|c|c|c|c|c|}
\hline \multirow{2}{*}{ Parameter } & \multicolumn{5}{|c|}{ Experimental diets } \\
\cline { 2 - 6 } & Control & D1 & D2 & D3 & D4 \\
\hline Plasma protein & $3.12^{\mathrm{c}} \pm 0.07$ & $3.35^{\mathrm{b}} \pm 0.06$ & $3.59^{\mathrm{ab}} \pm 0.02$ & $3.71^{\mathrm{a}} \pm 0.07$ & $3.69^{\mathrm{a}} \pm 0.06$ \\
\hline Plasma Albumin & $1.80^{\mathrm{a}} \pm 0.02$ & $1.53^{\mathrm{b}} \pm 0.03$ & $1.44^{\mathrm{c}} \pm 0.03$ & $1.32^{\mathrm{d}} \pm 0.02$ & $1.35^{\mathrm{d}} \pm 0.01$ \\
\hline Plasma Globulin & $1.32^{\mathrm{e}} \pm 0.06$ & $1.82^{\mathrm{d}} \pm 0.07$ & $2.15^{\mathrm{c}} \pm 0.05$ & $2.39^{\mathrm{a}} \pm 0.09$ & $2.34^{\mathrm{b}} \pm 0.06$ \\
\hline
\end{tabular}

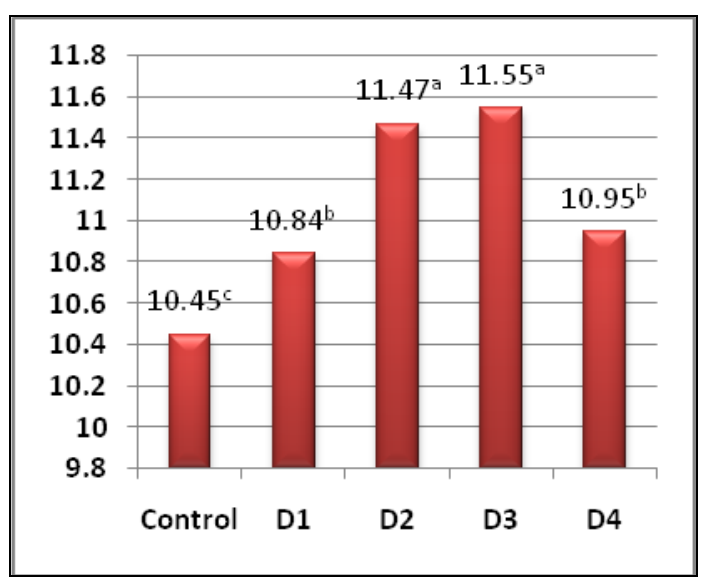

Fig. 9. IgM level

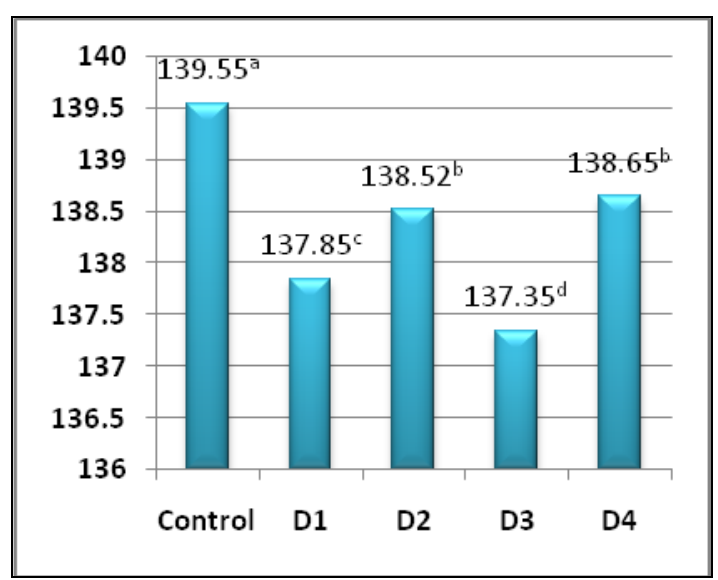

Fig. 10. IgD level

\section{Profit index study}

Regarding dietary amino acid and fatty acid of taro dried leaves, the effect of taro can be used as a possible alternative feed ingredient. In this regard, the use of cheap and readily available feed ingredient is important in maximizing nutritious and economic value (Tion \& Adeka, 2000).

For the analyses of both cost and benefits, taro leaf proved to beof low cost effectiveness when used as replacement of soybean meal in the diet of the tilapiafish (ElTawil et al., 2020).

Substitute expensive yellow corn and soybean meal by unconventional source of raw materials, as taro leaves which are uneaten by people, is a good trial to reduce cost of production and increase the supply of protein and carbohydrate in fish diet.

The present results showed that dried taro leaf is low cost effective when used as replacement of expensive and conventional meal (soy and corn) in the Nile tilapia rations. Therefore, using taro leaf meal as a good source of nutrients for fish diet is recommended for the low cost and high benefits.

\section{REFERENCES}

A.O.A.C. (2012). "Official Methods of Analysis of the Association of Official Analytical Chemistry." (A.O.A.C.) International, 19th ed., Gaithersburg, Maryland, USA.

Adane, T.; Shimelis, A.; Negussie, R.; Tilahun, B. and Gulilat, D., (2013). Effect of processing method on the proximate composition, mineral content and ant-nutritional 
factors of taro (Colocasia esculenta, L.) grown in Ethiopia. Africa Journal of Food, Agriculture, Nutrition and Development, 34: 1411-1488.

Ajijola, S.; Ajani, O. I. and Saka, J. O. (2003). Efficiency of resource use among cocoyam farmers in Owo Local Government area of Ondo State Nigeria. Moor J. Agric. Res., 4:281-287.

Akwee, P.E.; Netondo, G.; Kataka, J.A. and Palapala, V.A. (2015). A critical review of the role of taro (Colocasia esculenta (L.) Schott) to food security: A comparative analysis of Kenya and Pacific Island taro germplasm. Scientia Agriculturae, 9: 101- 108.

Armstrong, W.D. and Carr, C.W. (1964). Physiological chemistry laboratory directions. (3rd ed.). Burges Publishing Co. Minneapolis, Minnesota.

Behera, K.K.; Maharana, T.; Sahoo, S. and Prusti, A. (2009). Biochemical quantification of protein, fat, starch, crude fibre, ash and dry matter content in different collection and greater yam (Dioscorea alata L.) found in Orissa. Nature and Science, 7: 24-32.

Bligh, E.G. and Dyer, W.T (1959).A rapid method of total lipid extraction and purification. Can. J. Biochem. Physiol., 37: 911-917.

Carpenter, J.R. and Steinke, W.E. (2001). Breadfruit (Treculia Africana decene) seeds, J. Mat. In: taro, a review of Colocasis esculenta and its Res., 1: 16-25.

Castillo, S. and Gatlin, D.M. (2015). Dietary supplementation of exogenous carbohydrase enzymes in fish nutrition: A review. Aquaculture., 435: 286-292.

Chhay, T.; Borin, K.; Sopharith, N.; Preston, T.R. and Aye, T.M. (2010). Effect of sun-dried and fresh cassava leaves on growth of Tilapia (Oreochromis niloticus) fish fed basal diets of rice bran or rice bran mixed with cassava root meal. Livestock Research for Rural Development, 22 Article 43. Retrieved November 25, 2011.

Cho, C. Y. and Kaushik, S. J. (1985). Effects of protein intake on net metabiliable and net energy values of fish diets. In: Nutrition and feeding in fish, Academic Press, London, 95- 117.

Duncan, D.B. (1955). Multiple ranges and multiple F-tests. Biometrics, 11: 1-42.

El-Saidy, D.M. and Saad, A.S. (2008). Evaluation of cow pea seed meal, Vigna sinensis, as a dietary protein replacer for Nile tilapia, Oreochromis niloticus (L.), fingerlings. Journal of the World Aquaculture Society., 39: 636-645.

El-Sayed, A. M. (2004). Protein nutrition of farmed tilapia: Searching for unconventional sources. In New dimensions in farmed tilapia: proceedings of the Sixth International Symposium on Tilapia Aquaculture, 364-78. Manila, Philippines. World aquaculture society, Baton Rouge, Louisiana, USA.

El-Sayed, A. M. (2006). Tilapia culture in salt water: Environmental requirements, nutritional implications and economic potentials. 8th Symposium on Advances in Nutrition Aquaculture, November 15-17, 2006, Nuevo Leon, Mexico.

El-Tawil, N.; Ali, S. and El-Mesallamy, A. (2020). Effect of using taro leaves as a partial substitute of soybean meal in diets on growth performance and feed efficiency of 
the Nile tilapia Oreochromis niloticus. Egyptian Journal of Aquatic Biology \& Fisheries, 24(7): 383 - 396.

Feinstein, S.; Akov,Y.; Lachmi, B. E.; Lehrer, S.; Rannon, L. and Katz, D. (1985). Determination of human IgG and IgM class antibodies to West Nile virus by enzyme linked immunosorbent assay (ELISA). J Med Virol, 17(1): 63-72.

Furukawa, A. and Tasukahara, H. (1966). On the acid digestion method for determination of Chromic Oxide as an index substance in the study of digestibility of fish feed. Bulleten of Japanese Society of Sintific fisheries, 32:502-506.

Gornall, A.G.; Bardawill, C.L. and David, M.M. (1949). Determination of serum proteins by mean of the biuret reagent. J. Bio. Chem., 177: 751ppt.

Handel, E.V . (1965). Estimation of glycogen in small amount tissue. Ana. Biochem., 11: 256-265.

Hang, D.T. and Preston, T.R. (2009). Taro (Colocacia esculenta) leaves as a protein source for growing pigs in Central Viet Nam. Livestock Research for Rural Development 21 Article 164.

Hardy, R. W. (2010). Utilization of plant proteins in fish diets: Effects of global demand and supplies of fish meal. Aquaculture Research, 41: 770-776.

Hardy, R. W. and Tacon, A. G. J. (2002). Fish meal: Historical uses, production trends, and future outlook for supplies. In R. R. Stickney \& J. P. MacVey (Eds.), Responsible Marine Aquaculture (pp. 311-325). New York: CABI Publishing.

Jiang, G. (1999). The non-starch polysaccharides of taro (Colocasia esculenta). Doctor of philosophy. 139.

Kaushik, S. J. and Seiliez, I. (2010). Protein and amino acid nutrition and metabolism in fish. Current knowledge and future needs. Aquaculture Research, 41(3): 322-332.

Li, Y. B. and Watkins, A. (1998). Conjugated linoleic acids alter bone fatty acid composition and reduce ex vivo prostaglandin E2 biosynthesis in rate fed n-6 or n-3 fatty acids. Lipids, 33: 417-425.

Luyen, Q.H.; Chowdhury, M. H.; Choi, J.; Kang, J.; Park, N. G. and Hong, Y. (2012). Selection of a L-Lysine-overproducing strain of the red seaweed Porphyra suborbiculata (Rhodophyta) through mutation and analog enrichment. Journal of Fisheries and Aquatic Science, 15(2): 145-150.

Lyu, Z.; Chai, J.; Xu, Z. and Qin,Y. (2019). Environmental impact assessment of mining activities on groundwater: case study of copper mine in Jiangxi Province, China. Journal of Hydrologic Engineering, 24(1), 05018027.

Makori, A. J.; Abuom, P. O.; Kapiyo, R.; Anyona, D. N. and Dida, G. O. (2017). Effects of water physico-chemical parameters on tilapia (Oreochromis niloticus) growth in earthen ponds in Teso North Sub-County, Busia County. Fisheries and Aquatic Sciences, 20: 30 .

Mathia, W.M. and Fotedar, R. (2012). Evaluation of boiled taro leaves, Colocasia esculenta (L.) Schott, as a freshwater shrimp, Caridina nilotica Roux protein 
replacement, in diets of Nile tilapia, Oreochromis niloticus (Linnaeus) Aquaculture, 356357, 302-309

Melesse, A.; Tiruneh, W. and Negesse, T. (2011). Effects of feeding Moringa stenopetala leaf meal on nutrient intake and growth performance of Rhode Island Red chicks under tropical climate. Tropics and subtropics agroecosystems, 14(2): 485-492.

Mmanda, F. P.; Mulokozi, D. P.; Lindberg, J. E.; Haldén, A.N.; Mtolera, M.; Kitula, R. and Lundh, T. (2020) Fish farming in Tanzania: the availability and nutritive value of local feed ingredients, Journal of Applied Aquaculture, 32 (4): 341-360.

Ogunji, J.; Rahat-Ul-Ain, Summan, T. C. and Schulz, W. K. (2008). Growth performance, nutrient utilization of Nile tilapia (Oreochromis niloticus) fed housefly maggot meal (Magmeal) diets. Turkish Journal of fisheries and Aquatic Sciences, 8(1): 141-147.

Olaniyi, C.O. (2010). Effect of substituting Fish meal with Taro leaf meal on growth and blood profile of African Catfish (Clarias gariepinus Burchell) International Journal of Organic Agriculture Research and Development, 1 (1): 106-117.

Onifade, A.A. and Abu, O.A. (1998). Productive response of rabbits to supplemental copper in a diet based on tropical feedstuffs. J. Appl. Anim. Res., 13: 129-135.

Osek, M.; Janocha, A.; Klocek, B.; Wasilowski, Z. and Milczarek, A. (2004). Influence of the type of feed protein on the quality of carcasses and poultry meat. In: annual. Sciences. Zoot., 20:229-234.

Oueme, I.C and B. C. Winston, (1999). Tropical root and tuber crops: production, perspectives and future prospects. FAO Plant production and protection paper, 126. FAO, Rome.

Pereira, P. R.; Corr^ea, A. N. T.; Vericimo, M. A. and Paschoalin, V. F. (2018). Tarin, a Potential Immunomodulator and COX-Inhibitor Lectin Found in Taro (Colocasia esculenta). Comprehensive Reviews in Food Science and Food Safety, 17: 878- 891.

Pratriche, T.; Patriche, N.; Bocioc, E. and Coada, M.T. (2011). Serum biochemical parameter of farmed carp (C. carpio). International Journal of the Bioflux Society., 4 (2):137-140.

Raky, F.A. (2001). The use of fish meal replacers in fresh water aquaculture. $\mathrm{PhD}$ thesis, Faculty of Science, Zagazig University.

Raky, F.A.; Fadda, S.H. and Michael, F.R. (2021c). Biochemical and Nutritional Studies on the Nile Tilapia Fed Orange Peel Additive.Egyptian Journal of Aquatic Biology \& Fisheries, 25(5): 307 - 321.

Raky, F.A.; Fadda, S.H. and Salah El-Dein, S.A. (2021a). Effects of some feed additives on growth performance and physiological parameters of Oreochromis niloticus. Egyptian Journal of Aquatic Biology \& Fisheries, 25(4):807-821.

Raky, F.A.; Fadda, S.H. and Zaher, M.M. (2021b).Influence of olive leaves additive on growth and physiological parameters of Sarotherodon galilaeus.Egyptian Journal of Aquatic Biology \& Fisheries, 25(4): 967 - 979. 
Richter, N.; Siddhuraju, P. and Becker, K. (2003). Evaluation of nutritional quality of moringa (Moringa oleifera Lam.) leaves as an alternative protein source for Nile tilapia (Oreochromis niloticus L.). Aquaculture, 217:599-611.

Robaina, L.; Izquierdo, M.S.; Moyano, F.J.; Socorro, J.; Vergara, J.M.; Montero, D. and Fernandez-Palacios, H. (1995) Soybeanand lupin seed meals as protein sources in diets for gilthead seabream (Sparus aurata): nutritional and histological implications. Aquaculture, 130: 219-233.

Small, B. C. and Soares Jr., J. H. (1999). Quantitative dietary threonine requirement of juvenile striped Bass Morone saxatiles. Journal of World Aquaculture Society, 30: 319323.

SPSS, (1997). Statistical Package for the Social Sciences, Version 16, SSS in Ch, ChiUSA.

Temesgen, M.; Retta, N. and Tesfaye, E. (2017). Nutrient composition and digestibility of taro leaf in the diets of chicken and effects on the meat quality. J Nutr Health Food Eng., 7(3): 286-294.

Temesgen, M.; Retta, N. and Tesfaye, E. (2018). Chicken Amino Acid and Fatty Acid: Effect of Feeding Taro Leaf in the Diet. Acta Scientific Nutritional Health, 2(1): 12-18.

Tidwell, J. H.; Webster, C. D.; Yancey, D. H. and Abramo, L. R. (1993). Partial and total replacement of fish meal with soybean meal and distillers by-products in diets for pond culture of the freshwater Prawn (Macrobrachium rosenbergii). Aquaculture, 118: 119-130.

Tion, M.A. and Adeka, I. (2000). The evaluation of cassava root meal as replacement for maize in broiler diets. In: Proceedings of the 25thAnnual Conference, Nigerian Society of Animal Production. Michael Okpara, University of Agriculture, Umudike, Nigeria.

Toan, N.H. and Preston, T.R. (2010). Taro as a local feed resource for pigs in small scale house hold condition. Livestock Research for Rural Development, 22(152).

Wang, J. (1983). Book "Taro: a review of Colocasis esculenta and its potentials". 418 pp. ref.p. 367-394

Webster, C. D. and Chhorn, L. (2006). Tilapia: biology, culture and nutrition. CRC Press.

Wee, K.L. and Wang, S.S. (1987). Nutritive value of Leucaena leaf meal in pelleted feed for Nile tilapia. Aquaculture, 62:97-108.

Zhang, L.; Xu, E. G.; Li, Y.; Liu, H.; Vidal-Dorsch, D. E. and Giesy, J. P. (2018). Ecological risks posed by ammonia nitrogen (AN) and un-ionized ammonia (NH3) in seven major river systems of China. Chemosphere, 202: 136-144.

Zollner. N. and Kirsch, K. (1962). Uber die quantitative Bestiming von lipoden (Mikromethod) miltter der vielen natrulichen lipoden(allen bekannten plasma lipoden) gemeinsamen sulfophosphovallin- reaktion. Z. ges.Exp. Med., 135: 545-561. 